Revista Iberoamericana, Vol. LXXXIII, Núm. 258, Enero-Marzo 2017, 119-133

\title{
LA CONSONANCIA DE LA CASA BARROCA CON EL SUEÑO DE SOR JUANA
}

\author{
POR \\ SAng Kee Song \\ Universidad de Corea
}

Sor Juana Inés de la Cruz (1651?-1695) y Gottfried Wilhelm Leibniz (1646-1716) son contemporáneos en el sentido que Octavio Paz da a su exclamación "Somos contemporáneos" en su ensayo "A Literature of Foundation" (4). Aunque no existe mención alguna a los libros de Leibniz en la lista de cuatro mil libros de Sor Juana, ambos compartían el concepto de Zeitgeist en el ocaso de lo Barroco. La hipótesis de mi estudio es que lo que comparte Sor Juana en su poesía más rigurosa, El Sueño (1692), con el Discurso del método (1637) de René Descartes, es menos vinculable que la relación entre El Sueño y la Monadología (1714).

Es cierto que hay cierta reminiscencia de Descartes en El Sueño, tal como demuestran Electa Arenal y Susan McKenna. El Sueño es el producto de una visión como la de Descartes, en la cual vislumbra una fusión de teología, poesía y ciencia (Arenal 125). Del mismo modo que Descartes aplicó el pensamiento racional para probar la existencia de Dios en los capítulos tercero y quinto de sus Meditaciones, el pensamiento cartesiano ejerce un rol significativo en El Sueño (McKenna39). McKenna atribuye el evento de la ascensión y la caída del alma a la oscuridad escolástica del período colonial y este movimiento rectilíneo viene de la intuición del silogismo (43). La analogía del cuerpo con la máquina y la subsiguiente descripción del corazón ("el reloj humano") y del pulmón ("respirante fuelle") es la huella del Discurso del método (44). McKenna proclama que el lenguaje de Sor Juana y su sistema epistemológico se ven afectados por los textos que protagonizaron la revolución científica (44). Sor Juana, tanto como Leibniz, es discípula del racionalismo cartesiano en el sentido que, para ellos, el ser humano se alarma y se ve intimidado ante el universo infinito pero también es a la vez capaz de adquirir el conocimiento total si aplica apropiadamente el método del saber. La añoranza y el tratado de la práctica del conocimiento total eran obsesiones de Descartes, Leibniz y Sor Juana. Pero el mundo imaginario de Descartes 
es rectilíneo, basado en la extensión del cuerpo y la proyección del alma, mientras que en Sor Juana y en Leibniz la curvatura predomina en el universo. "Si Descartes no ha sabido resolver el secreto del continuo del laberinto del alma y sus predicados es porque ha buscado el secreto del continuo en trayectos rectilíneos, y el de la libertad en una rectitud del alma, ignorando tanto inclinación del alma como la curvatura de la materia" (Deleuze 11). En Leibniz, la curvatura del universo se prolonga según tres nociones fundamentales: la fluidez de la materia, la elasticidad de los cuerpos y el resorte como mecanismo (Deleuze 13). En El Sueño, después de la caída del alma metaforizada por Ícaro y Faetón, que son símbolos de caracteres desviados, el alma se recupera de la ceguera y realiza un movimiento curvo como resorte de su búsqueda del conocimiento profundo, tal como propone Aretusa en el meandro. Según Mabel Moraña, este resorte es un repliegue, "ya no sólo el doblez sino el retroceso estratégico que vuelve a proponerse como avance, que se desdice de su direccionalidad para volver a proyectarse y desplegarse" (129). Para Mabel Moraña, la única crítica de la arquitectura barroca que expone el contraste entre el lenguaje exacerbado de las fachadas y la supuesta paz del interior, tiene especial relevancia en la estrategia discursiva que despliega en la obra de Sor Juana:

\begin{abstract}
Si el constructo barroco se define principalmente por su opacidad, por el ocultamiento y revelación parcial y ambivalente del sentido y del sujeto individual y colectivo lo que genera, donde la norma (la ortodoxia, el dogma, la autoridad) es constantemente confirmada pero también impugnada por estrategias transgresivas, innovadoras y reivindicativas, la obra de la monja mexicana es justamente de la tensión que une intimidad y espacio público, pensamiento y palabra, fe y razón, clausula y apertura hacia las contradicciones y desafíos del siglo. (...) Como mujer y monja, subalterna eclesiástica y dueña de letras en los espacios controlados de la corte y el convento, sor Juana ejerce todas las formas posibles de teatralidad, desde la creación de una persona extraordinaria pero verosímil a través del constructo autobiográfico, hasta el montaje polifónico y carnavalizados de loas y villancicos, desde las alegorizaciones que dan forma didáctica a la idea y la doctrina hasta los seudónimos, retratos y enigmas que revelan y encubren al sujeto que los inventa. Pliegues, despliegues y repliegues de una identidad individual, sectorial y genérica en proceso de autoconstrucción. (130-31)
\end{abstract}

Aquí, Moraña lee a Leibniz a través de El pliegue: Leibniz y el Barroco (1988) de Gilles Deleuze. Su lectura está basada en la máscara o el disfraz dicotómico del contraste de lo interior y lo exterior y su travestismo, que lo hace viceversa. Ahora analizaré esta intersección audaz y la elipsis barroca como un movimiento de una Mónada que disuelve y reconcilia la cacofonía y el conflicto en el orden cósmico. El alma del yo poético en El Sueño atraviesa y peregrina en el cosmos barroco aún conectado con el cuerpo. La Mónada de Leibniz no es un mero conjunto de binarismo del alma y el cuerpo, de lo interior y lo exterior. Por la intersección de la Mónada, la

111 Revista Iberoamericana, Vol. LXXXII, Núm. 258, Enero-Marzo 2017, $119-133$ 
frontera se vuelve reinterpretada. Voy a analizar El Sueño vislumbrando el claroscuro misterioso y la armonía dentro de las cacofonías con la lectura contrapunteada de la Monadología y El Pliegue.

La sombra y la oscuridad no son contrastadas con la luz ni es exterior a la luz, sino un lienzo que compone unas protuberancias minuciosas del pliegue que, a su vez, compone un color y se conecta activamente con la luz. Este lienzo es el cuerpo en el que se manifiesta el alma, la cual no se separa del cuerpo para ascender o peregrinar en busca de la verdad y cae al cuerpo con el bautizo de la luz, tal como establece la interpretación generalizada de El Sueño, sino más bien como una Mónada que forma el ser viviente y orgánico que contiene el cuerpo y el alma, que es un espejo del orden del Universo (Leibniz 124). Las Mónadas son formas del ser sustanciales al ámbito metafísico, como los átomos al ámbito físico y fenomenal. En las Mónadas "no hay partes, tampoco hay extensión, ni figura, ni divisibilidad posibles" (Leibniz 105). Todos los cambios y las acciones de la Mónada son programados y desplegados como un autómata natural:

Tampoco hay medio de explicar cómo una Mónada puede ser alterada o cambiada en su interior por alguna otra criatura, puesto que en ella no cabe transponer nada ni concebir movimiento interno alguno que pueda ser excitado, dirigido, aumentado o disminuido dentro de ella, como sí es posible en los compuestos, en donde hay cambio entre las partes. Las Mónadas no tienen ventanas por las que pueda entrar o salir algo. Los accidentes no pueden desprenderse ni andar fuera de las sustancias, como hacían antaño las especies sensibles de los escolásticos. Así pues, ni sustancia ni accidente alguno puede entrar en una Mónada. (Leibniz 106)

Así Leibniz explica que "los cambios de las Mónadas provienen de un principio interno, puesto que una causa externa no puede influir en su interior" (107). Lo que me llama la atención es la construcción arquitectónica de la casa barroca que no tiene ventanas por donde se filtre la luz exterior. Pero hay una pormenorización de lo que está cambiando que especifica y varía las sustancias simples:

El estado transitorio que envuelve y representa una multitud en la unidad o en la sustancia simple no es otra cosa que lo que llamamos Percepción, que debemos distinguir de la apercepción o conciencia, como luego quedará de manifiesto. Y precisamente en este punto los cartesianos han caído en un grave error, por no haber tenido en cuenta para nada las percepciones de las que no nos apercibimos. A causa de esto también han creído que solamente los Espíritus eran Mónadas y que no había Almas de las Bestias ni otras Entelequias; y han confundido, junto con el vulgo, un largo aturdimiento con

$111 \frac{\text { Revista Iberoamericana, Vol. LXXXII, Núm. 258, Enero-Marzo 2017, } 119-133}{\text { ISSN 0034-9631 (Impreso) }}$ 
una muerte en sentido riguroso, por lo que han venido a caer de nuevo en el prejuicio escolástico de las almas completamente separadas, y han corroborado, incluso, a los espíritus retorcidos en la opinión de la mortalidad de las almas. (Leibniz 108)

El alma es todo lo que tiene percepciones y apetitos y lo que lleva memoria. Leibniz redefine el alma como una entidad que siente la percepción y ejerce la entelequia, el término aristotélico que refiere una cosa que está trabajando activamente en sí misma para la perfección, y que se opone al concepto de potencialidad. Descartes pensó que el alma está separada del cuerpo al que ambos están conectados por una glándula dentro del cuerpo. Leibniz niega la influencia directa del cuerpo en el alma. Más bien, ve la conformidad del alma y del cuerpo orgánico:

El alma sigue sus propias leyes, el cuerpo, asimismo, las suyas; pero convienen entre
sí en virtud de la armonía preestablecida entre todas las sustancias, puesto que todas
ellas son representaciones de un mismo universo. Las almas actúan según las leyes
de las causas finales, por medio de apeticiones, fines y medios. Los cuerpos actúan
según las leyes de las causas eficientes o de los movimientos. Y ambos reinos, el de
las causas eficientes y el de las causas finales, están entre sí, en armonía. (129-30)

El alma y el cuerpo actúan por sus propias leyes. Y no hay interacción directa entre sí. Pero sus movimientos propios disimulan ser comunicados en armonía como en una orquesta. El mundo de Leibniz está lleno de analogías de máquinas independientes que conforman una armonía compositiva. En El Sueño hay muchas analogías entre alma y cuerpo, personajes mitológicos y alusiones de la poetisa y su entorno, ceguera y revelación, universo y tierra, etc.

Pese a la diferencia de la publicación, la Monadología y El Sueño empezaron a bosquejarse en la década tardía de 1680. Octavio Paz supone que El Sueño "debe haber sido escrito alrededor de 1685" (Sor Juana 469). Leibniz escribió "Meditaciones de Cognición, Verdad e idea" en 1684, artículo en el que declara la analogía entre la idea de Dios y la de hombre, y la identidad entre la lógica de Dios y la del hombre. Aquí ya estaba bosquejando la Monadología, pero sin usar el término Mónada. El inventio simultáneo significa la imposibilidad de la comunicación intelectual entre los dos autores, uno en Alemania la otra en Nueva España. Pero también sugiere que ellos compartían el mismo episteme y la representación latente de la misma época. Sor Juana estudió teología escolástica y ciencia natural, y tuvo acceso al Hermetismo a través de los libros de Athanasius Kircher y la filosofía mecanicista de René Descartes. Leibniz leyó a Galileo, Francis Bacon, Thomas Hobbes y Descartes. El quería reconciliar a estos pensadores modernos con Aristóteles (convertido por la teología escolástica). También estuvo interesado en Kircher y Giordano Bruno, como Sor Juana (Song 270). Entrenada en la filosofía escolástica que la religión Católica implantó en el Nuevo

111 Revista Iberoamericana, Vol. LXXXII, Núm. 258, Enero-Marzo 2017, $119-133$ 
Mundo, Sor Juana quería captar el conocimiento del mundo y del universo a través de la vasta lectura y la agudeza de su intelecto en medio de los oficios del convento de San Jerónimo y la querella dentro de la Iglesia. Leibniz, como diplomático e inventor, tuvo que reconciliar el conflicto entre catolicismo y protestantismo. En las corrientes filosóficas de los dos intelectuales representantes del Viejo Mundo y el Nuevo Mundo yacen el vitalismo aristotélico, el mecanismo cartesiano y la emanación transcendental neoplatónica. En una época en que se ve amenazada la razón teológica escolástica, predomina el pathos del nihilismo del desengaño y brota el sentido de modernidad con el capitalismo protestante, Leibniz se ofreció para servir como abogado de Dios y como árbitro en el conflicto de las religiones, y Sor Juana ejerció el papel de promotora de la teología revolucionaria que critica agudamente el dogma de la teología anticuada.

El Sueño de Sor Juana Inés de la Cruz puede ser interpretado como una peregrinación del alma, que es una Mónada que no se separa del cuerpo en el cosmos arquitectónico de lo Barroco. El esquema de Mónada de Leibniz no es una mera dicotomía entre lo interior y lo exterior, alma y cuerpo. Leibniz opera una renovación profunda de la distinción de los dos mundos. En su Monadología, Leibniz diseña la casa de lo Barroco. Esta casa la concreta Gilles Deleuze en El pliegue. Esta casa se divide en dos pisos: una planta baja perforada por cinco ventanas, las cuales sugieren los cinco sentidos, y poblada con materia y animales; y un primer piso sin ventanas y decorado con una pantalla llena de pliegues. En un piso, están los repliegues de la materia; en el otro piso, los pliegues del alma. La luz se permuta entre los dos:

Es cierto que los dos pisos comunican (por eso el continuo remonta al alma). Abajohay almas, sensitivas, animales, o incluso hay un piso de abajo en las almas, y los repliegues de la materia las rodean, las envuelven. Cuando hayamos comprendido que las almas no pueden tener una ventana hacia afuera, eso habrá que aplicarlo, al menos en primer lugar, a las almas de arriba, razonables, que han ascendido al otro piso ("elevación"). El piso superior no tienen ventana: habitación o gabinete oscuro, revestido de una tela tensa "diversificada por pliegues", como una dermis en carne viva. Esos pliegues, cuerdas o resortes constituidos sobre la tela opaca, representan los conocimientos innatos, pero que pasan al acto bajo las solictaciones de la materia. Pues ésta desencadena "vibraciones u oscilaciones" en la extremidad inferior de las cuerdas, mediante "algunas pequeñas aberturas" que existen en el piso inferior. Leibniz realiza un gran montaje barroco, entre el piso de abajo perforado de ventanas, y el piso de arriba, ciego y cerrado, pero en cambio resonante, como un salón musical que traduciría en sonidos los movimentos visibles de abajo. (Deleuze, 12)

El cuarto oscuro de arriba recibe las vibraciones de la materia de abajo por los flecos o cordones de su cortina, que cuelgan por unas pocas aperturas que comunican los dos pisos. De este modo "la casa barroca pone en escena la gran armonía entre cielo y tierra, y alma y cuerpo" (Hanneken 595).

$111 \frac{\text { Revista Iberoamericana, Vol. LXXXIII, Núm. 258, Enero-Marzo 2017, } 119-133}{\text { ISSN 0034-9631 (Impreso) }}$ 


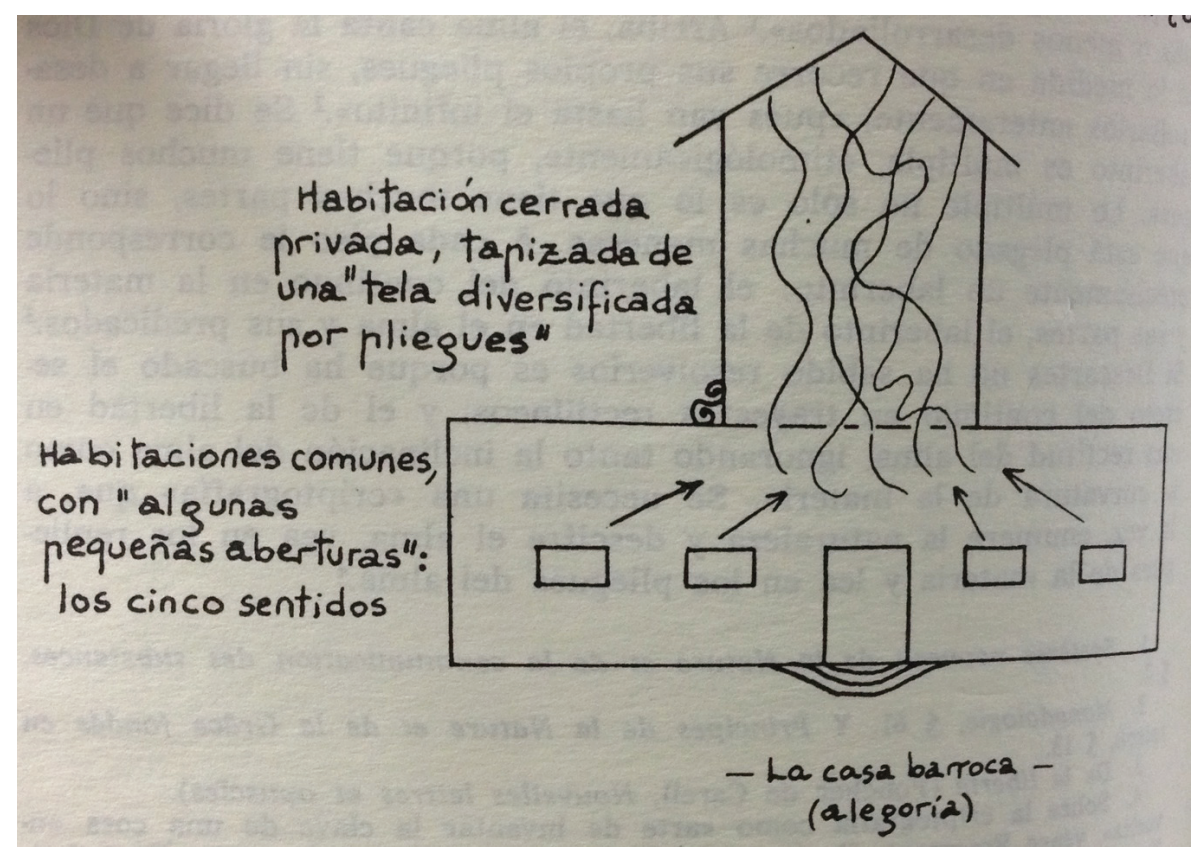

Lámina 1. La casa barroca (Deleuze 12)

En El Sueño, dentro de la máscara de la dicotomía de alma contra cuerpo, luz contra sombra y consonancia contra disonancia, hay cierta disolución entre los dos expresados como "penumbra", "el informe embrión", "la luz fugitiva". El mundo poético de Sor Juana se despliega en El Sueño como un manifiesto de alma maquinaria y material, como la Mónada de Leibniz.

Para Leibniz, visto por Deleuze, la característica de lo Barroco es el pliegue que avanza hacia el infinito. La alegoría de la casa barroca se lee como una analogía entre el espacio y el ser. Y al ser "las Mónadas, en sí mismas, incorpóreas" (Leibniz 138), tuvo que vislumbrar un espacio donde atraviesan las Mónadas:

El Barroco no remite a una esencia, sino más bien a una función operatoria, a un rasgo. No cesa de hacer pliegues. [...] El rasgo del Barroco es el pliegue que va hasta el infinito. En primer lugar, el Barroco diferencia los pliegues según dos direcciones, según dos infinitos, como si el infinito tuviera dos pisos: los repliegues de la materia y los pliegues en el alma. Abajo, la materia es acumulada según un primer género de pliegues, después organizada según un segundo género, en la medida en que sus partes constituyen órganos plegados diferentemente y más o menos desarrollados. Arriba, el alma canta la gloria de Dios en la medida en que recorre sus propios pliegues, sin 
llegar a desarrollarlos enteramente, pues van hasta el infinito. Se dice que un laberinto es múltiple, etimológicamente, porque tiene muchos pliegues. Lo múltiple no sólo es lo que tiene muchas partes, sino lo que está plegado de muchas maneras. A cada piso le corresponde precisamente un laberinto: el laberinto del continuo en la materia y sus partes, el laberinto de la libertad en el alma y sus predicados. (Deleuze 11)

La interpretación predominante entre los críticos de la parte introductoria de $E l$ Sueño es la de Paz, para quien la sombra que representa el alma de Sor Juana asciende para buscar el conocimiento absoluto (Sor Juana 485), lo cual sugiere el Hermetismo introducido por Kircher. Pero también es posible leer este pasaje, en el esquema de la casa barroca, como una relación dialéctica de la luz y la sombra, no como una relación antagonista:

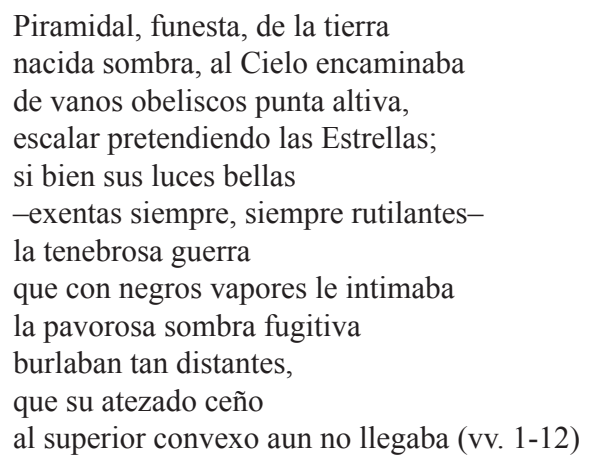

Aquí, en el esquema de la casa barroca, la "nacida sombra" en vez de la luz quiere infiltrarse hasta la cúspide del universo supralunar para llegar a las luces de las estrellas. No es la luz la que se infiltra en la cámara oscura de la planta primera, sino la sombra, como el alma de Dante en el Purgatorio que proyecta a un punto del peregrinar. "El piso de arriba se cierra, puro interior sin exterior, interioridad cerrada en ingravidez, tapizada de pliegues espontáneos que ya sólo son los de un alma o de un espíritu" (Deleuze 43). Lo esencial de la Mónada es que tiene un fondo sombrío (Deleuze 42). El empuje de la sombra (Mónada) hacia lo alto y su hundimiento son movimientos típicos de lo Barroco. Este movimiento es posible porque la Mónada tiene autonomía dentro de su interioridad claustrada. Es un interior sin exterior. Pero tiene como correlato la independencia de la fachada, exterior sin interior. La fachada tiene sus puertas y agujeros. Para que no haya el vacío, estos agujeros tienen que ser sutiles. Sólo se abre la ventana desde afuera. "Las luces bellas exentas y rutilantes" vienen de las fachadas, "las Estrellas". El pliegue es el atravesar y el ascenso de un alma de un viviente dentro de la Mónada (la sombra funesta), la interioridad absoluta 
como principio metafísico de la vida hacia (las luces de las estrellas), la fachada, la exterioridad infinita de la materia. Ninguno de los dos se junta con el otro. Pero hay un tenue repliegue entre la superficie de los dos pisos por el cual asciende el alma, tal como vemos en El entierro de Conde de Orgaz de El Greco. Pero no hay necesidad de ver luz y sombra, "como 0 y 1 , como dos pisos del mundo separados por una tenue línea de aguas: los Bienaventurados y los Condenados" (Deleuze 46). Para evitar esta oposición manierista, Deleuze da el ejemplo barroco de Tintoretto y Caravaggio, que preparan "el cuadro con un fondo sombrío marrón-rojo sobre el que colocan las sombras más espesas, y pintan directamente degradando hacia las sombras" (47). Luego contemplando las frases de Leibniz, con mucha audacia define el nuevo régimen de luz:

\begin{abstract}
Leibniz dice en La profesión de fe del filósofo:
"La luz se filtra como por una hendidura en medio de las tinieblas". ¿Debemos entender que procede de un tragaluz, de una pequeña abertura acodada o plegada, por medio de espejos consistiendo lo blanco en un gran número de pequeños espejos reflectantes? Más rigurosamente, al carecer las mónadas de hendiduras, en cada una hay una luz sellada, y esa luz se enciende cuando la mónada es elevada a la razón, y produce lo blanco por todos los pequeños espejos interiores. Produce lo blanco, pero también produce la sombra: produce lo blanco, que se confunde con la parte iluminada de la mónada, pero que se oscurece o se degrada hacia el fondo sombrío, de donde surgen las cosas gracias a sombreados y tintes más o menos fuertes y utilizados. Sucede como en Desargues, basta con invertir la perspectiva o poner lo luminoso en lugar del ojo, lo opaco en lugar del objeto y sombra en lugar de la proyección. (Deleuze 47)
\end{abstract}

Esta contemplación acerca de la inversión de luz y sombra es muy sugestiva al leer El Sueño. La sombra es la proyección del yo poético que tiene luz sellada que se eleva a la razón o con una cierta perspectiva para aclarar el objeto opaco. Y con la aclaración espontánea se vuelve ilustrada por un momento con su propia luz que antes estaba enclaustrada. Pero de pronto se oscurece. "El claro no cesa de estar inmerso en lo oscuro" (47). Esta inseparabilidad entre lo claro y lo oscuro, la relatividad de la claridad como la de movimiento y desaparición del contorno fueron unas ideas ajenas a Descartes, que fue un hombre del Renacimiento. La Mónada, que está llena de claroscuro, es un ser transitorio que despliega su pliegue o recorre el claro sobre el fondo sombrío. Los caracteres mitológicos que sufren metamorfosis en El Sueño surgen en este trasfondo:

$$
\begin{aligned}
& \text { Con tardo vuelo y canto, del oído } \\
& \text { mal, y aun peor del ánimo admitido, } \\
& \text { la avergonzada Nictimene acecha } \\
& \text { de las sagradas puertas los requicios } \\
& \text { o de las alaboyas eminentes }
\end{aligned}
$$

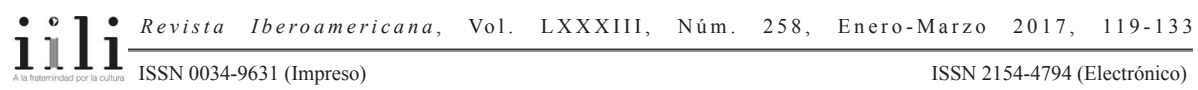




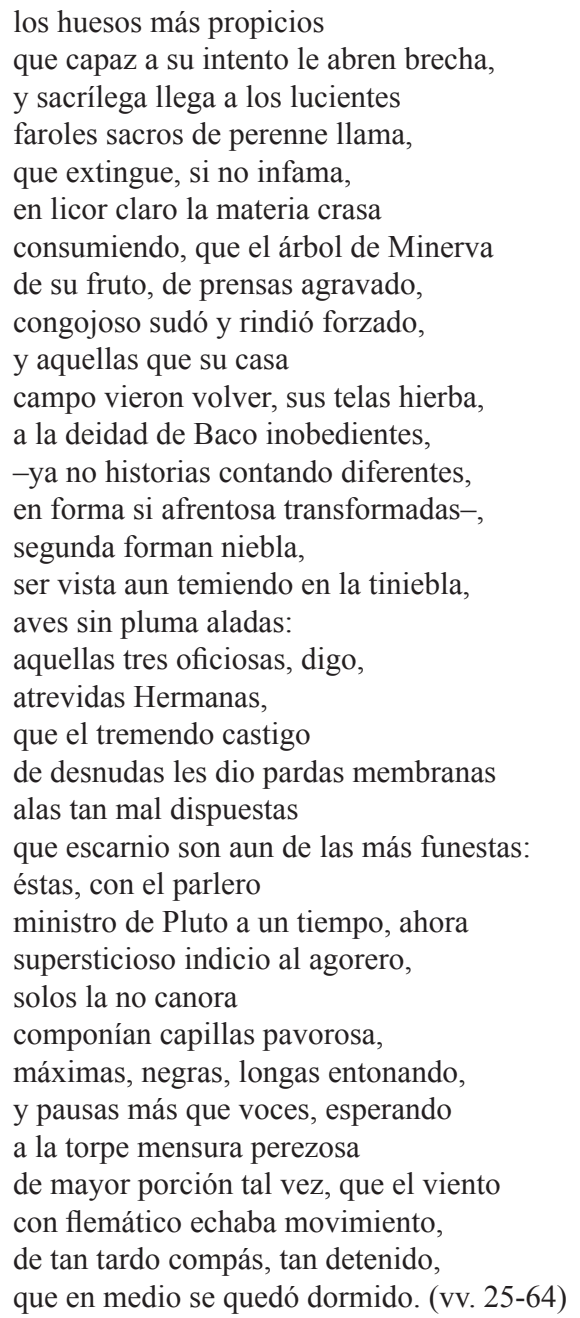

Nictimene, que quiere beber el licor claro de Minerva, la Diosa de la sabiduría, por la hendidura de la luz barroca, se convirtió en búho que sólo canta en mal oído. Aunque ella hace un trabajo vergonzoso que hurta la labor intelectual de otros, como señala Jean Franco (34), hay que notar que Minerva y Nictimene son de la misma especie. Sea lo que sea, Nictimene, que se transformó en búho y que tiene los ojos grandes para el misterio del universo, es la proyección o la metamorfosis del alma sombría de Sor Juana. Minerva es el estar potente de Nictimene. 
Las tres hermanas que se transformaron en murciélagos por sacrilegio contra la deidad Baco, también cantan un coro disonante, "no canoro". La homofonía de la melodía que hizo en mal oído a Nictimene conlleva la variación de la polifonía con el coro sin melodía en "la entonación longa con pausas más que voces". La música barroca es la expresión del sentimiento. Una disonancia no preparada es la expresión de la desesperación y de la congoja. El sonido rasgado por el dolor se infiltra en el aire en un tono más grueso y disidente. La diferencia de los trémulos minuciosos hace la disonancia congojosamente. Cuando el dolor no expresa su melodía paulatinamente "con más pausas que voces", aparece el placer del silencio. Luego la disonancia puede convertirse en la armonía en el pliegue del acorde muy lento. Las ondas ultrasónicas del murciélago tejen una música trascendental con el trémulo de la textura que está fuera de la aprehensión del ser humano (Song 274). Para el ser humano solamente por la melodía se realiza el acorde. Este contraste del universo de la música en El Sueño encaja también en la casa barroca:

Cuando la casa deviene musical: el piso de arriba comprende las mónadas verticales armónicas, los acordes interiores que cada una produce en su habitación respectiva, la correspondencia o concertación de estos acordes; el piso de abajo se extiende a lo largo de una infinidad de líneas melódicas horizontales, incluidas las unas en las otras, donde, a la vez, enriquece sus variaciones y desarrolla su continuidad sensibles; pero es porque lo alto se pliega sobre lo bajo, según la tonalidad, para realizar en él los acordes. La armonía se realiza en la melodía. (Deleuze 174)

Acordes verticales e insensibles de las ondulaciones ultrasónicas se armonizan en las melodías sensibles y terrenales. La sombra de Sor Juana, que se ha convertido en los pájaros nocturnos, sube al vacío donde no hay ningún trémulo minucioso del aire, al silencio que es el máximo grado de la música celestial.

Cuando la oscuridad y el silencio sin fluctuación de la fulminosa sonoridad dominaba el mundo, Acteón (vv. 97-128), otra alegoría del sujeto epistemológico del yo poético, miró a Artemisa, consagrada a la castidad, que estaba bañándose. Ella lo transformó en un ciervo como castigo por haberla profanado al verla desnuda, y luego envió a sus perros para que lo mataran. Así el sujeto cazador se transforma en objeto de caza. Sor Juana se sitúa a sí misma en un pobre ciervo que está atento al asalto de los perros. Por la mirada en que el sujeto se sumerge al objeto, Sor Juana se objetiviza a sí misma en un carácter mitológico para dar otro matiz al imperio del silencio. Como Alcíone (vv. 89-96), que está despierta aún en el silencio del mar, el alma sombría de Sor Juana se alza en busca de un sujeto epistemológico más elevado en el contorno de la oscuridad y del silencio. Por este proceso, su alma se transforma en un sujeto más elevado hasta identificarse con Ícaro (vv. 430-509) y con Faetón (vv. 760-826). En esta proyección hacia los personajes mitológicos que trataron de volar hacia la infinitud,

$111 \frac{\text { Revista Iberoamericana, Vol. LXXXIII, Núm. 258, }}{11}$ Enero-Marzo 2017, $119-133$ 
el yo poético muestra su simpatía más que la reprensión a la osadía y a la arrogancia. Aretusa (vv. 712-729) es el último personaje mitológico que el yo poético proyecta. Es la diosa del arroyo con su meandro subterráneo que busca a Perséfone, que había sido raptada por Plutón. El movimiento del meandro sugiere una búsqueda empírica con "la curiosidad útil”. Su movimiento horizontal subterráneo contrasta con el movimiento vertical celeste de Ícaro y Faetón. Estas tres figuras se forman en un cono con sus vuelos y el meandro. La proyección y transformación en los personajes mitológicos son útiles para disimular la ambición intelectual del yo poético. Este no se define en un predicado, sino en varios accidentes-predicados hasta llegar al máximo grado, a un "yo despierta". Esta serie de alegorías que se descubre a sí mismo y al mundo según el orden del tiempo, convierte al sujeto en mundo y transforma el mundo en sujeto:

El propio objeto es ampliado según toda una red de relaciones naturales, él es el que desborda su marco para entrar en un ciclo o una serie, y el concepto se encuentra cada vez más condensado, interiorizado, envuelto en una instancia que en el límite podemos llamar personal: tal es el mundo en cono o en cúpula, cuya base, siempre en extensión, ya no se relaciona con un centro, sino que tiende hacia una punta o un vértice. (Deleuze 161)

En el panorama del abismo de la sombra a "yo despierta" ilustrada, la alegoría de la disonancia lenta de Nictimene peregrina hacia la consonancia absoluta en forma de la signatura compacta. Pero el sabor de este poema se pliega no en la consonancia en la luz, sino en el banquete de la disonancia de la sombra, y construye la arquitectura más solemne y suntuosa de lo Barroco.

La imagen del cono también se adecua al cuerpo. La descripción minuciosa del cuerpo dormido (vv. 200-291) muestra el proceso de auto-producción del cuerpo orgánico. Aunque recibe la energía por la comida desde el exterior, es el sistema desde el que se sigue al programa intrínseco dentro del sistema. Cuando domina Morfeo, el dios del sueño, el alma que acaso se liberó del dominio de la percepción exterior, sólo distribuye "los gajes del calor vegetativo a los miembros lánguidos" (vv. 195200). En aquel entonces, pulmón y corazón son testigos fieles que prueban estar vivo. El quilo que es mixto por sangre y linfa se esparce por todo el cuerpo y empuja los humos que nutrirán a cuatro cualidades (juicio, imaginación, memoria y fantasía) de las percepciones internas en el cerebro. Con estos humos, el cerebro entrega los simulacros a la memoria para que se guarden más claramente que antes de dárselos a la imaginación. También le da espacio a la fantasía para que las imágenes se formen en una pantalla, como el Faro de Alejandría. Las imágenes copian todas las cosas. En el modo posible que pueda concebirse, el pincel invisible representa las imágenes y las muestra al alma (vv. 282-291). El cuerpo finito produce la fantasía por el sistema auto-reproductivo o por el pliegue que despliega. Es la mirada interna que lo Barroco

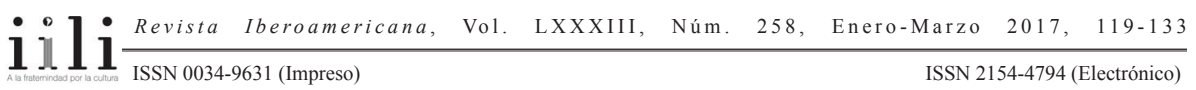


proyecta al infinito. Y el alma, de manera sutil, capta las imágenes. "De este corporal conocimiento" el yo poético quiere avanzar a la comprensión de "compendio misterioso [...] al supremo pasar maravilloso compuesto triplicado" que es el misterio del ser humano que tiene cualidades de los vegetales, animales y ángeles" (vv. 652-660). La pantalla en la que proyecta la linterna mágica que Leibniz inventó es, de hecho, "una zona de expresión privilegiada, clara y distinta" (Deleuze 111). Debemos tener el cuerpo oscuro para que deje esa zona más clara. Los accidentes singulares que incluyen los predicados de la Mónada forman una zona clara de expresión. Estos accidentes se relacionan con el cuerpo a que pertenece la Mónada y se realizan dentro de los cuerpos que reaccionan con este cuerpo. Cada alma no se puede separar del cuerpo y está en este cuerpo proyectándose al mundo y a sí misma:

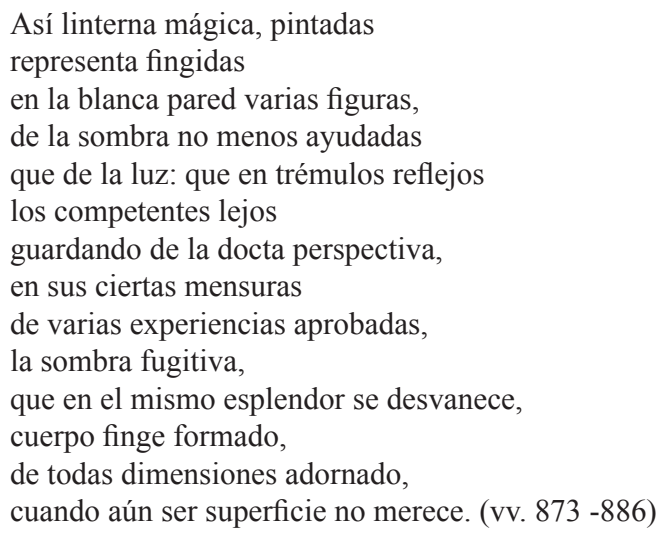

Sor Juana, como Leibniz, aprecia la función de la oscuridad, que no es menos importante que la de la luz. Aquí, el yo poético contempla el mecanismo de la comprensión y del conocimiento que se captó por la pirámide de la oscuridad antes de la formación de la pirámide de la luz. Las dos pirámides de Memphis que menciona el yo poético son la pirámide de la oscuridad y la pirámide de la luz. Estas son las matrices esenciales de la representación y del conocimiento del yo poético al mundo, al universo y al cuerpo de la parte anterior y de la parte posterior a lo largo de 975 versos. En la parte anterior, dentro de la pirámide de la oscuridad o dentro del cono de la sombra, el alma por el cuerpo de Sor Juana, el sujeto cognitivo, trata de comprender el universo y el mundo con cierta inclinación. Es una comprensión construida por la fantasía que viene de la experiencia y del sentimiento dentro del sujeto que se diferencia con la esencia del mundo exterior. No es el entendimiento pasivo adquirido por la unión con Dios como en el caso del misticismo. Más bien, es una proyección al mundo comprendido y

$111 \frac{\text { Revista Iberoamericana, Vol. LXXXIII, Núm. 258, }}{11}$ Enero-Marzo 2017, $119-133$ 
compuesto por la voluntad de Sor Juana. Pero esta proyección activa resulta ser ajena y alejada del conocimiento del objeto real.

La unidad interna y alta y la unidad exterior y ancha son compatibles dentro del esquema del cono. Desde hace mucho tiempo que se proyectaba un universo infinito, este universo perdió su centro, al haber tantas formas posibles de universo. Pero la originalidad de lo Barroco es justamente otorgar otra vez la unidad del universo por la proyección a cierto punto, como el punto de perspectiva del ser humano.

que como sube en piramidal punta

al Cielo la ambiciosa llama ardiente,

así la humana mente

su figura trasunta,

y a la Causa Primera siempre aspira,

-céntrico punto donde

la línea, si ya no circunferencia,

que contiene, infinita, toda esencia- (vv. 404-411)

Por la infinitud de la Causa Primera, que es la potencia inmensa de Dios, la circunstancia se vuelve la línea para que contenga toda esencia. Pero esto no es la línea recta cartesiana de la extensión, sino la línea basada de la infinitud de las curvaturas, la multitud inmensa de los accidentes en que su coeficiente o diferencial se vuelve cero. Esta esencia de Dios, que es inmanente a todos los seres, brota cuando la Mónada sombría tiene la luz:

Consiguió, al fin, vista del ocaso

al fugitivo paso,

$\mathrm{y}$-en su mismo despeño recobrada

esforzando el aliento en la rüina-,

en la mitad del globo que ha dejado

el Sol desamparada,

segunda vez rebelde determina

mirarse coronada,

mientras nuestro Hemisferio la dorada

ilustraba del Sol madeja hermosa,

que con luz judiciosa

de orden distributivo, repartiendo

a las cosas visibles sus colores

iba, y restituyendo

entera a los sentidos exteriores

su operación, quedando a luz más cierta

el mundo iluminado, y yo despierta. (vv. 958-975) 
Por fin, se aparece la pirámide o el cono de la luz que tiene la forma inversa de la pirámide o el cono de la oscuridad. Aquí está abajo el punto de la perspectiva de la luz que luce el yo poético, "yo despierta”. Este cono de la luz es más bien bergsoniana, donde las memorias puras o el estado potente desciende hacia al sujeto del aquí y ahora. Ahora se completa el esquema de las dos pirámides en este poema, que son dos procesos o programas diferentes del conocimiento. En la pirámide de la oscuridad, se formó la fantasía con la languidez del cuerpo y adquirió "el informe embrión", un pliegue más simple, por el entendimiento intuitivo o por la manera deductiva. El meandro de Aretusa que amplía la planicie sugiere el método inductivo. Esta planicie aumenta al estado potente del sujeto. En la pirámide de la luz, este estado potente o la subconsciencia freudiana (la sombra) es asaltada por la consciencia iluminada (la luz) y por el despliegue de la luz se despierta el yo poético en "el mundo iluminado". Es una transición de un sueño tramado por las alegorías a la consciencia más iluminada. Por la proporción dialéctica (feedback) de las dos pirámides, el yo poético llega a conocer y comprender el mundo en una forma espiral. El imperio de la noche territorializada por el sol desterritorializará el imperio solar para que otorgue el placer de autosuficiencia de sueños alegóricos.

\section{BiBLIOGRAFÍA}

Alatorre, Antonio. "Lectura del Primero Sueño". Y diversa de mí misma entre vuestras plumas ando: Homenaje internacional a Sor Juana Inés de la Cruz. Sara Poot Herrera, ed. México D.F.: El Colegio de México, 1993.

Arenal, Electa. "Where Woman is Creator of the World or, Sor Juana's Discourses on Method" (1991): 124-41.

Cruz, sor Juana Inés de la. Obras completas. México D.F.: Porrúa, 2004.

Deleuze, Gilles. El pliegue: Leibniz y el Barroco. José Vazquez y Umbertina Larraceleta, ed. Buenos Aires: Paidós, 2005.

Franco, Jean. Plotting Women: Gender and Representation in Mexico. New York: Columbia UP, 1989.

Hanneken, Jaime. "Los pliegues de Paradiso". Revista de Estudios Hispánicos 45 (2011): 593-614.

Jolley, Nicholas. Leibniz. London: Routledge, 2005.

Leibniz, G. W. Monadología: Principios de filosofía. Julián Velarde, ed. Madrid: Biblioteca Nueva, 2012.

Moraña, Mabel. Viaje al silencio: Exploraciones del discurso barroco. México D.F.: UNAM, 1998.

McKenna, Susan M. "Rational Thought and Female Poetics in Sor Juana's Primero

Sueño: Representation of the Developing Intellect and Critical Spirit of New Spain”. Hispanic Review 68/1 (2000): 37-52. 
Nanfito, Jacqueline C. "El Sueño: The Baroque Imagination and the Dreamscape". MLN 106/2 (1991): 423-31.

Olivares-Zorilla, Rocío. "The Eye of Imagination: Emblems in the Baroque Poem The Dream, by Sor Juana Inés de la Cruz.” Emblematica: An Interdisciplinary Journal for Emblem Studies 18 (2010): 111-63.

Paz, Octavio. "A Literature of Foundations." The Tri-Quarterly Anthology of Contemporary Latin American Literature. José Donoso y Wiliam A. Henkin, eds. New York: Dutton, 1969. 2-8.

Sor Juana Inés de la Cruz, o las trampas de la fe. Barcelona: Seix Barral, 1982.

Penn, Sheldon. "Oneiric Landscapes of Creation: Visions of Life and Death in José Gorostiza's Muerte sin fin". Romance Studies 29/4 (2011): 225-68.

Ramírez, Goretti. "La cueva del mago y la sala del museo: lectura de Primero sueño de sor Juana Inés de la Cruz”. Revista de Estudios Hispánicos 35 (2001): 3-20.

Rensoli Laliga, Lourdes. "Inconsciente, sueño y muerte en la concepción antropológica de G. W. Leibniz". Letras de Deusto 26/73 (1996): 153-76.

Robinson, Beatriz(2012), "Las ensaladas de Sor Juana y el barroco novohispano: la representación solidaria y poética de una nación en gestación”. Confluencia 28/1 (2012): 104-117.

Song, Sang Kee. "La sombra barroca del Sueño de Sor Juana Inés de la Cruz leída como una mónada de Leibniz”. Estudios Hispánicos 38 (2006): 269-87.

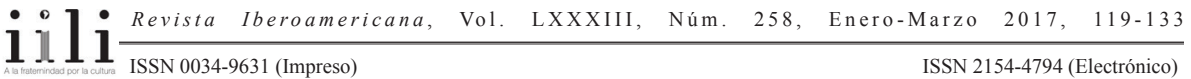


